Article

\title{
Synthesis of anisole by vapor phase methylation of phenol with methanol over catalysts supported on activated alumina
}

\author{
Dan Dang, Ze Wang*, Weigang Lin, Wenli Song \\ State Key Laboratory of Multi-Phase Complex Systems, Institute of Process Engineering, Chinese Academy of Sciences, Beijing 100190, China
}

\section{A R T I C L E I N F O}

Article history:

Received 19 February 2016

Accepted 25 February 2016

Published 5 May 2016

\section{Keywords:}

Phenol

Methanol

Catalysis

Anisole

Methylation

\begin{abstract}
A B S T R A C T
The synthesis of anisole by vapor phase methylation of phenol with methanol over activated alumina (AA) supported catalysts was investigated in a fixed bed reactor. $\mathrm{KH}_{2} \mathrm{PO}_{4} / \mathrm{AA}$ gave the best performance among the eight tested catalysts. The catalyst was prepared by loading $\mathrm{KH}_{2} \mathrm{PO}_{4}$ on $\mathrm{AA}$ and then calcining at the optimized temperature of $700{ }^{\circ} \mathrm{C}$ for $8 \mathrm{~h}$. In the vapor phase reaction, the level of anisole yield (LAY) has a maximum at $400-450^{\circ} \mathrm{C}$ when the temperature varied from 300 to 500 ${ }^{\circ} \mathrm{C}$, which decreased slightly with increasing WHSV and increased distinctly with increasing mole fraction of methanol. On comparing 0-methylation and C-methylation of phenol, a low temperature, high WHSV (short residence time), and a low methanol concentration over the $\mathrm{KH}_{2} \mathrm{PO}_{4} / \mathrm{AA}$ catalyst with higher $\mathrm{K}$ contents were found to increase anisole selectivity by O-methylation of phenol. The reaction routes to the major products and the catalytic mechanism were suggested, and a 'K-acid' bifunctional process may be a critical factor to the formation of anisole.
\end{abstract}

(C) 2016, Dalian Institute of Chemical Physics, Chinese Academy of Sciences. Published by Elsevier B.V. All rights reserved.

\section{Introduction}

Anisole is an important industrial chemical and intermediate product used for perfumes, flavoring agents, and organic synthesis [1,2]. Anisole is usually synthesized by a liquid phase process in an alkaline environment, such as the reaction between sodium phenolate and dimethyl sulfate, the reaction between bromobenzene and methanol, and the reaction between sodium phenolate and chloromethane [2]. However, these processes have been severely restricted in recent years because the alkali used are harmful to the environment and the extremely toxic raw materials like dimethyl sulfate and bromobenzene are dangerous to human health. So, a green process for anisole synthesis is needed, and a vapor phase catalytic reaction was proposed.

The synthesis of anisole by a vapor phase reaction between phenol and dimethyl carbonate (DMC) has been investigated [2-5]. DMC, a green chemical material that is used for methylation, can be synthesized from the oxidative carbonylation of methanol [6], but the synthesis of DMC increases the complexity and cost of the anisole synthetic process. So, another method that uses methanol for direct methylation to replace DMC was studied [1,7-9]. However, in the reaction between phenol and methanol, the product composition is more complicated, and the product from 0-methylation (methylation on the oxygen atom of the phenolic hydroxyl group) of phenol is more difficult to obtain compared to that from C-methylation (methylation on the carbon atom of the aromatic ring) [10-16]. Kirichenko et al. [1] obtained a high anisole selectivity of $93.9 \%$ with a phenol conversion rate of $81 \%$ with the catalysis of $\mathrm{NaX}$ at $320{ }^{\circ} \mathrm{C}$. Sarala et al. [16] found that the existence of cesium in samarium phosphate enhanced anisole selectivity by suppressing

\footnotetext{
* Corresponding author. Tel: +86-10-82544963; Fax: +86-10-82622893; E-mail: wangze@ipe.ac.cn

This work was supported by the National Natural Science Foundation of China (51476180) and the National Basic Research Program of China (973 Program, 2014CB744304).
}

DOI: 10.1016/S1872-2067(15)61074-9 | http://www.sciencedirect.com/science/journal/18722067 | Chin. J. Catal., Vol. 37, No. 5, May 2016 
C-alkylated side products. A high anisole yield of $83 \%$ was obtained at $350{ }^{\circ} \mathrm{C}$. Generally, compared to the DMC approach, the synthesis of anisole from the methylation of phenol with methanol is less satisfactory, and the mechanism is rather vague. Therefore, further study on the vapor phase catalytic reaction for anisole preparation is of great significance.

In this paper, the synthesis of anisole by vapor phase methylation of phenol with methanol over a $\gamma-\mathrm{Al}_{2} \mathrm{O}_{3}$ supported catalyst was studied. The vapor phase reaction conditions of temperature, space velocity, feed ratio of phenol to methanol, and catalyst synthesis conditions including the type and loading amount of the metal salts, and the calcination temperature were examined for level of anisole yield optimization. A catalytic mechanism was deduced.

\section{Experimental}

\subsection{Catalyst preparation}

The catalyst was prepared by the impregnation method in which a metal salt was loaded on the support of activated alumina (AA, $\gamma-\mathrm{Al}_{2} \mathrm{O}_{3}$ ) granules (diameter around $2 \mathrm{~mm}$ ). $\gamma-\mathrm{Al}_{2} \mathrm{O}_{3}$ granules was washed with distilled water and dried at $120{ }^{\circ} \mathrm{C}$ for $12 \mathrm{~h}$ first, and then cooled to room temperature for use. A salt solution was slowly added to a known amount of $\gamma-\mathrm{Al}_{2} \mathrm{O}_{3}$ granules according to the isopyknic impregnation rules. The impregnated $\gamma-\mathrm{Al}_{2} \mathrm{O}_{3}$ granules were then placed in open air at room temperature for $24 \mathrm{~h}$, and finally calcined in a muffle furnace for $8 \mathrm{~h}$ (the calcining temperature was $700{ }^{\circ} \mathrm{C}$ unless otherwise specified).

\subsection{Catalyst characterization}

The metal content on the $\gamma-\mathrm{Al}_{2} \mathrm{O}_{3}$ support was measured by inductively coupled plasma-atomic emission spectrometry (ICP-AES, IRIS Intrepid II XSP). The chemical phase of the catalyst was analyzed by X-ray diffraction (XRD) with a D/teX-Ultra detector and $\mathrm{Cu} K_{\alpha}$ radiation.

\subsection{Apparatus and procedure for the vapor phase reaction}

The schematic of the experimental system is shown in Fig. 1. The liquid reactant mixture of phenol and methanol and a stream of nitrogen as carrier gas were introduced into a fixed bed reactor by a peristaltic pump and mass flowmeter, respectively. The fixed bed reactor was a quartz tube (length of 600 $\mathrm{mm}$ and inner diameter of $27 \mathrm{~mm}$ ) placed coaxially in an electric furnace. About $20 \mathrm{~g}$ catalyst granules were loaded inside the reactor. When the set temperature was reached, the carrier gas of nitrogen $(100 \mathrm{~mL} / \mathrm{min})$ was introduced into the reactor to purge out air. Then the liquid reactants were fed into the reactor. The products were taken out of the reactor and sent to a condensing unit, which comprised a Graham condenser and two bottles located in an ice-water bath. The product was condensed to liquid and collected in the bottles. In each run, the time on stream was $3 \mathrm{~h}$.

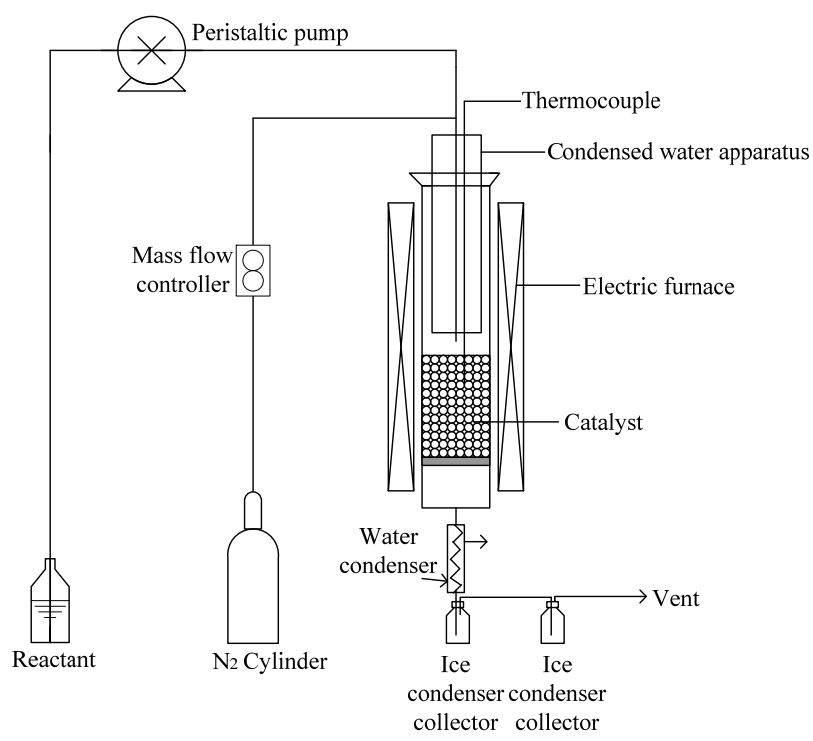

Fig. 1. Schematic of the lab scale apparatus for vapor phase synthesis of anisole.

\subsection{Product analysis}

To get the conversion of phenol and selectivity for anisole, the total liquid in the two bottles were weighed after the experiment. The liquid composition was analyzed by GC/MS (gas chromatography combined with mass spectrometry). The absolute amount of phenol remaining in the liquid product was determined by the internal standard method. The compound of isoamyl acetate (IAA) was used as the internal standard. The conversion of phenol was defined as the ratio of the mass of converted phenol to the original mass of phenol fed into the reaction system. However, the amounts of other components were not quantified by the internal standard because the correlation was not as good as that for phenol. Therefore, the selectivity of a liquid product was denoted by its area percentage among the major products, and accordingly the arithmetic product by multiplication between the phenol conversion rate (wt\%) and the anisole selectivity (area\%) was used to represent the level of anisole yield (LAY). The analytical conditions by GC/MS (Varian 3800GC/300MS with FFAP column of $25 \mathrm{~mm} \times 0.25 \mathrm{~mm} \times 0.2 \mu \mathrm{m}$ ) were as follows: oven temperature started from $40{ }^{\circ} \mathrm{C}$, hold for $3 \mathrm{~min}$, then increased by $4{ }^{\circ} \mathrm{C} / \mathrm{min}$ to $100{ }^{\circ} \mathrm{C}$, hold for $3 \mathrm{~min}$, and finally increased to $240{ }^{\circ} \mathrm{C}$ by 6 ${ }^{\circ} \mathrm{C} / \mathrm{min}$ and hold for $10 \mathrm{~min}$; the injector temperature was 240 ${ }^{\circ} \mathrm{C}$ and the ion source temperature was $250{ }^{\circ} \mathrm{C}$. The error analysis of the experimental system was conducted by three repeated experiments. The standard deviation of phenol conversion rate was $1.88 \%$. The standard deviation of anisole selectivity was $0.42 \%$.

\section{Results and discussion}

\subsection{Catalyst preparation conditions}

\subsubsection{Influence of the type of metal salt on catalyst} performance 
Table 1

Catalytic performance due to the type of metal salt impregnated in $\gamma-\mathrm{Al}_{2} \mathrm{O}_{3}$.

\begin{tabular}{|c|c|c|c|c|c|c|c|}
\hline \multirow{2}{*}{ Salt } & \multirow{2}{*}{$\begin{array}{l}\text { Metal content } \\
(w t \%)\end{array}$} & \multirow{2}{*}{$\begin{array}{l}\text { Phenol conversion } \\
\text { (wt } \%)\end{array}$} & \multicolumn{5}{|c|}{ Selectivity (area\%) } \\
\hline & & & Anisole & Methyl anisole & BTX & Methyl phenol & Others \\
\hline None & 0 & 100 & - & - & 45.01 & 12.47 & 42.52 \\
\hline $\mathrm{NaCl}$ & 5.23 & 72.76 & 27.68 & 6.58 & - & 64.73 & 0.91 \\
\hline $\mathrm{KH}_{2} \mathrm{PO}_{4}$ & 4.44 & 75.12 & 90.04 & 2.13 & - & 2.02 & 5.81 \\
\hline $\mathrm{MgCl}_{2}$ & 1.11 & 97.94 & - & - & 40.31 & 23.82 & 35.87 \\
\hline $\mathrm{Fe}_{2}\left(\mathrm{SO}_{4}\right)_{3}$ & 3.20 & 100 & - & - & 19.24 & 60.92 & 19.85 \\
\hline $\mathrm{Co}\left(\mathrm{NO}_{3}\right)_{2}$ & 7.47 & 100 & 0.62 & - & 40.58 & 49.03 & 9.77 \\
\hline $\mathrm{ZnCl}_{2}$ & 6.76 & 100 & - & - & 40.40 & 28.11 & 31.49 \\
\hline $\mathrm{La}\left(\mathrm{NO}_{3}\right)_{3}$ & 1.45 & 100 & - & 3.10 & 16.49 & 58.64 & 21.77 \\
\hline $\mathrm{Ce}\left(\mathrm{NO}_{3}\right)_{3}$ & 2.55 & 100 & 0.78 & - & 20.98 & 59.97 & 18.27 \\
\hline
\end{tabular}

BTX: Benzene-toluene-xylene.

The type of metal salt impregnated on the $\mathrm{Al}_{2} \mathrm{O}_{3}$ support was first investigated under reaction conditions of a temperature of $400{ }^{\circ} \mathrm{C}$, weight hourly space velocity (WHSV) of $0.21 \mathrm{~h}^{-1}$, and mole ratio of phenol to methanol of 1:5. Table 1 summarizes the conversion of phenol and selectivities for some main product components. The metal content was obtained from ICP-AES analysis. It can be seen from Table 1 that $\mathrm{KH}_{2} \mathrm{PO}_{4} / \mathrm{AA}$ enhanced both phenol conversion and anisole selectivity. So, in the following work, the catalyst of $\mathrm{KH}_{2} \mathrm{PO}_{4} / \mathrm{AA}$ was used for further investigation.

\subsubsection{Influence of calcination temperature on the performance of $\mathrm{KH}_{2} \mathrm{PO}_{4} / \mathrm{AA}$}

The effect of calcination temperature on the catalytic performance of $\mathrm{KH}_{2} \mathrm{PO}_{4} / \mathrm{AA}$ ( $\mathrm{K}$ content of $8.75 \mathrm{wt} \%$ ) is shown in Fig. 2 . The vapor phase reaction was conducted under the same conditions as given before. It can be seen that the phenol conversion was higher at the calcination temperatures of 500 and $700{ }^{\circ} \mathrm{C}$, and reached the highest value of $72.34 \%$ at $700{ }^{\circ} \mathrm{C}$. Anisole is the main product and the other products were methylanisole, methylphenol, and dimethylphenol, with a high anisole selectivity of over $98 \%$. The selectivity to anisole varied slightly in a reverse trend to that of methylanisole. This indicated that the consecutive conversion of anisole to methylanisole is a major cause of the decrease of anisole. The slight variation of ani-

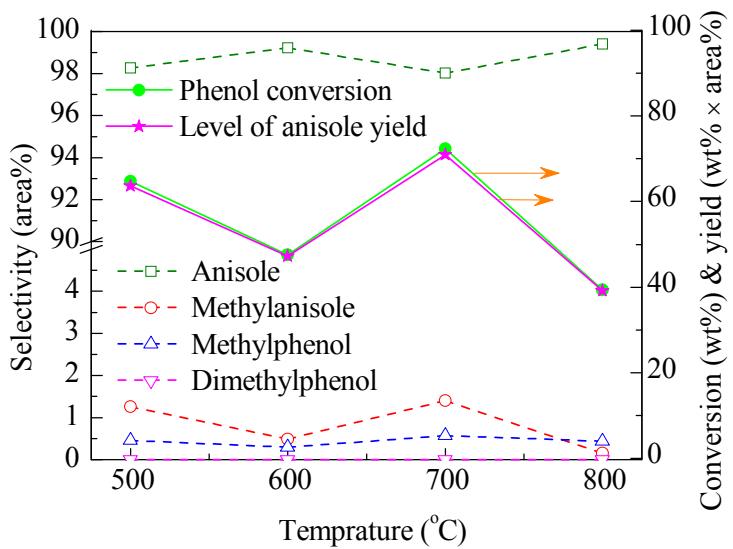

Fig. 2. Effect of calcination temperature on the performance of $\mathrm{KH}_{2} \mathrm{PO}_{4} / \mathrm{AA}$. sole selectivity and significant change of phenol conversion gave a similar trend of LAY to that of phenol conversion with increasing calcination temperature. A highest LAY of $70.92 \%$ appeared at $700^{\circ} \mathrm{C}$ as well.

XRD analysis of $\mathrm{KH}_{2} \mathrm{PO}_{4} / \mathrm{AA}$ calcined at different temperatures are shown in Fig. 3. It can be seen that a new chemical phase of $\mathrm{K}_{3} \mathrm{Al}_{2}\left(\mathrm{PO}_{4}\right)_{3}$ was generated on the $\gamma-\mathrm{Al}_{2} \mathrm{O}_{3}$ support. In particular, the peak intensity of $\mathrm{K}_{3} \mathrm{Al}_{2}\left(\mathrm{PO}_{4}\right)_{3}$ was more distinct at the calcination temperature of 600 and $800{ }^{\circ} \mathrm{C}$, which was opposite to the better performances of the catalysts calcined at 500 and $700{ }^{\circ} \mathrm{C}$ on the phenol conversion. This indicated that too much $\mathrm{K}_{3} \mathrm{Al}_{2}\left(\mathrm{PO}_{4}\right)_{3}$ generated was disadvantageous for the catalyst activity.

\subsubsection{Effect of $\mathrm{K}$ content on the performance of $\mathrm{KH}_{2} \mathrm{PO}_{4} / \mathrm{AA}$}

Under the same reaction conditions given above, the effect of $\mathrm{K}$ content on the performance of $\mathrm{KH}_{2} \mathrm{PO}_{4} / \mathrm{AA}$ was investigated as shown in Fig. 4. It can be seen that the phenol conversion generally decreased with increasing $\mathrm{K}$ content and in particular decreased faster with $\mathrm{K}$ content of over $7.53 \mathrm{wt} \%$. In contrast, the selectivity to anisole increased rapidly with a low $\mathrm{K}$ content and became stable with increasing $\mathrm{K}$ content after $4.44 \mathrm{wt} \%$. The selectivities of the other components exhibited a

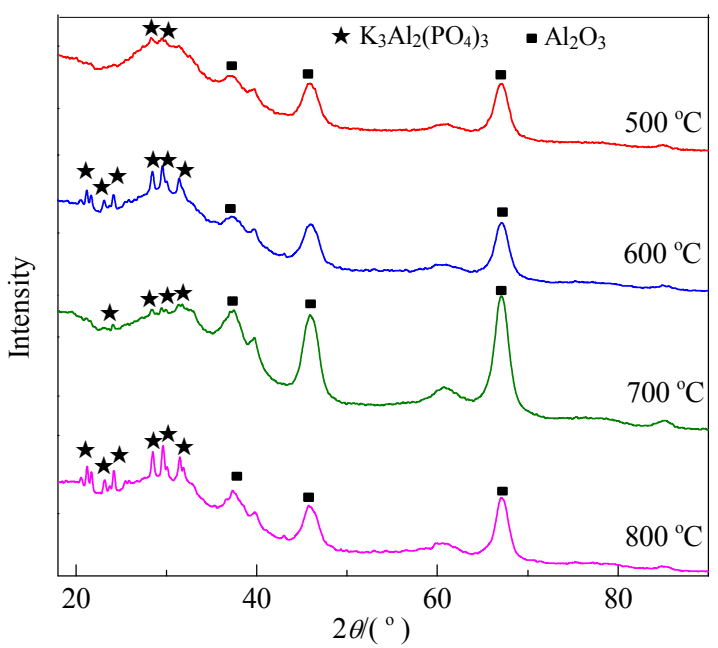

Fig. 3. XRD patterns of $\mathrm{KH}_{2} \mathrm{PO}_{4} / \mathrm{AA}$ at different calcination temperatures. 


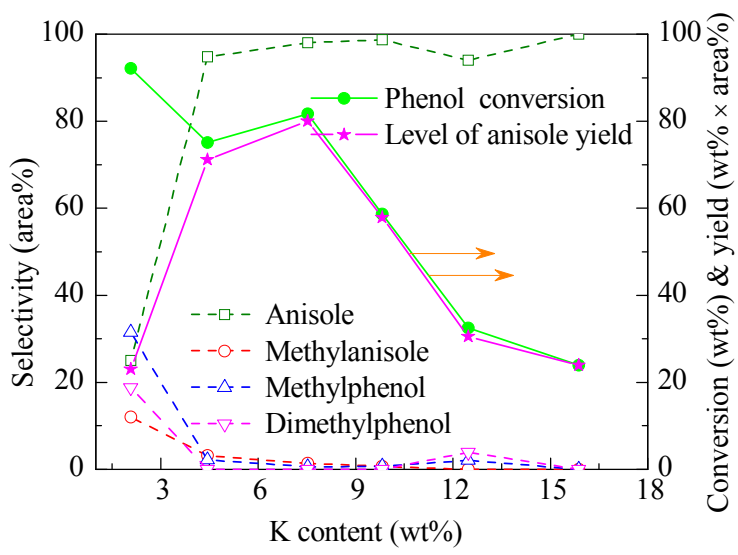

Fig. 4. Effect of $\mathrm{K}$ content on the performance of $\mathrm{KH}_{2} \mathrm{PO}_{4} / \mathrm{AA}$.

common reverse trend to that of anisole. In particular, the selectivity of methyphenol was the highest and even higher than that of anisole at the lowest $\mathrm{K}$ content. This indicated that a low $\mathrm{K}$ content was advantageous for $\mathrm{C}$-methylation conversion of phenol, while a high content of $\mathrm{K}$ favored the conversion of phenol by $\mathrm{O}$-methylation, illustrating the importance of $\mathrm{K}$ on the formation of anisole. By multiplication between the two factors of conversion and selectivity of anisole, the LAY reached the highest of $80.06 \%$ at the $\mathrm{K}$ content of $7.53 \mathrm{wt} \%$.

The $\mathrm{KH}_{2} \mathrm{PO}_{4} / \mathrm{AA}$ catalysts with different $\mathrm{K}$ loadings were analyzed by XRD, as shown in Fig. 5. It can be seen that only the peaks of $\mathrm{Al}_{2} \mathrm{O}_{3}$ could be detected on the catalysts with low $\mathrm{K}$ contents. For the catalysts with $\mathrm{K}$ contents at 7.53-12.48 wt\%, the peaks of $\mathrm{Al}_{2} \mathrm{O}_{3}$ were reduced and simultaneously the peaks of $\mathrm{K}_{3} \mathrm{Al}_{2}\left(\mathrm{PO}_{4}\right)_{3}$ appeared distinctly with increasing $\mathrm{K}$ content. By considering the performance of the catalyst, the middle value of $7.53 \mathrm{wt} \%$ was the optimum $\mathrm{K}$ content for the highest selectivity to anisole.

\subsection{Influence of vapor phase reaction conditions on the performance of $\mathrm{KH}_{2} \mathrm{PO}_{4} / \mathrm{AA}$}

Under the catalysis of $\mathrm{KH}_{2} \mathrm{PO}_{4} / \mathrm{AA}$, the influence of vapor phase reaction conditions including the reaction temperature,

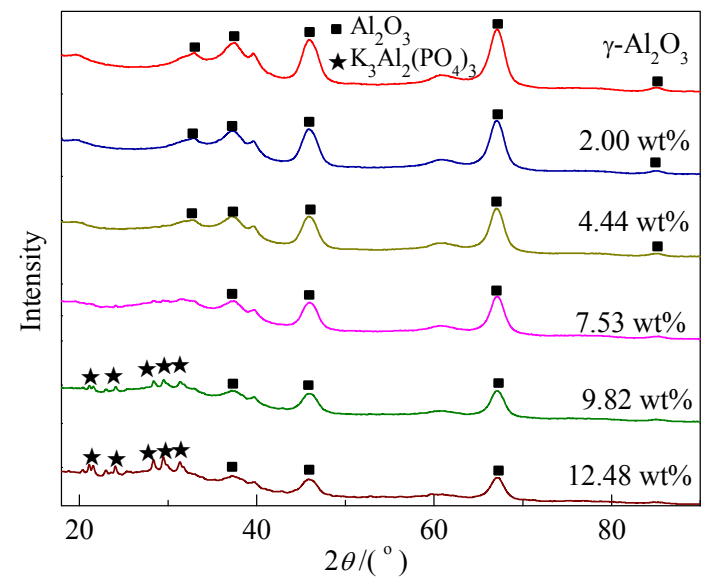

Fig. 5. XRD patterns of $\mathrm{KH}_{2} \mathrm{PO}_{4} / \mathrm{AA}$ with different $\mathrm{K}$ contents.
WHSV, and molar ratio of phenol to methanol on the conversion of phenol, selectivity to anisole, and level of anisole yield were investigated.

\subsubsection{Influence of temperature}

Fig. 6 shows the influence of reaction temperature on the performance of $\mathrm{KH}_{2} \mathrm{PO}_{4} / \mathrm{AA}$ (K content $7.72 \mathrm{wt} \%$ ). The reaction was conducted at temperatures from 300 to $500{ }^{\circ} \mathrm{C}$ with a constant WHSV of $0.21 \mathrm{~h}^{-1}$ and mole ratio of phenol to methanol of 1:5. It can be seen that the phenol conversion increased with increasing temperature from 300 to $500{ }^{\circ} \mathrm{C}$. Anisole was the main product at low temperatures, and its amount decreased slowly with increasing temperature and decreased much faster at high temperatures over $450{ }^{\circ} \mathrm{C}$. The selectivities of the other three components increased with increasing temperature, and in particular, the formation of methylphenol was promoted most significantly at high temperatures. This indicated that a low temperature favored the 0-methylation of phenol, and the C-methylation of phenol was prevalent at high temperatures. As the arithmetic product of phenol conversion and anisole selectivity, the LAY reached the highest value of $77.5 \%$ at the temperature of $400-450{ }^{\circ} \mathrm{C}$, indicating an optimal operating temperature range.

\subsubsection{Influence of WHSV}

The influence of WHSV on the performance of $\mathrm{KH}_{2} \mathrm{PO}_{4} / \mathrm{AA}$ (K content 8.45 wt\%) was investigated as shown in Fig. 7. The reaction was conducted under different WHSVs, which were controlled by a varied feeding rate of the reactant mixture, while the other conditions were constant at $400{ }^{\circ} \mathrm{C}$ and mole ratio of phenol to methanol of 1:5. It can be seen that phenol conversion decreased with increasing WHSV. Anisole selectivity increased slightly with the increase of WHSV, while the other products slightly decreased. This indicated that anisole was a primary product, and thus a shorter residence time was advantageous for a higher selectivity to anisole. The decreased phenol conversion and the slightly varied anisole selectivity determined a decreasing trend of LAY with a similar trend to that of phenol conversion with increasing WHSV, and a high LAY over $70 \%$ was obtained at a low WHSV less than $0.18 \mathrm{~h}^{-1}$.

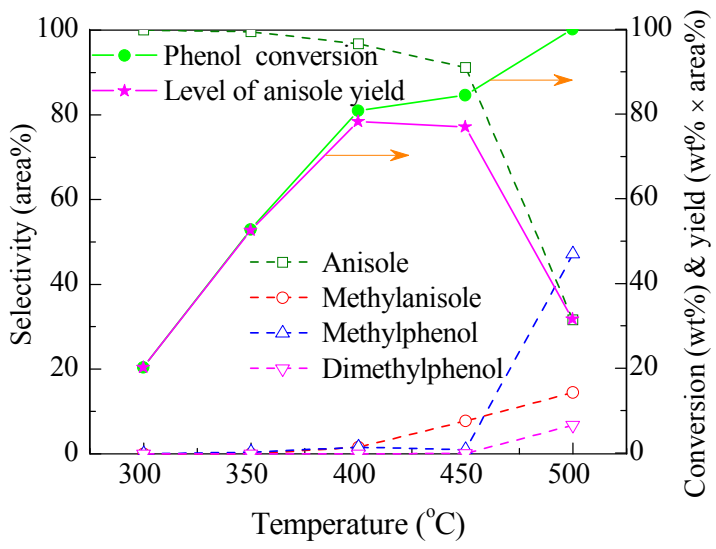

Fig. 6. Effect of reaction temperature on the performance of $\mathrm{KH}_{2} \mathrm{PO}_{4} / \mathrm{AA}$. 


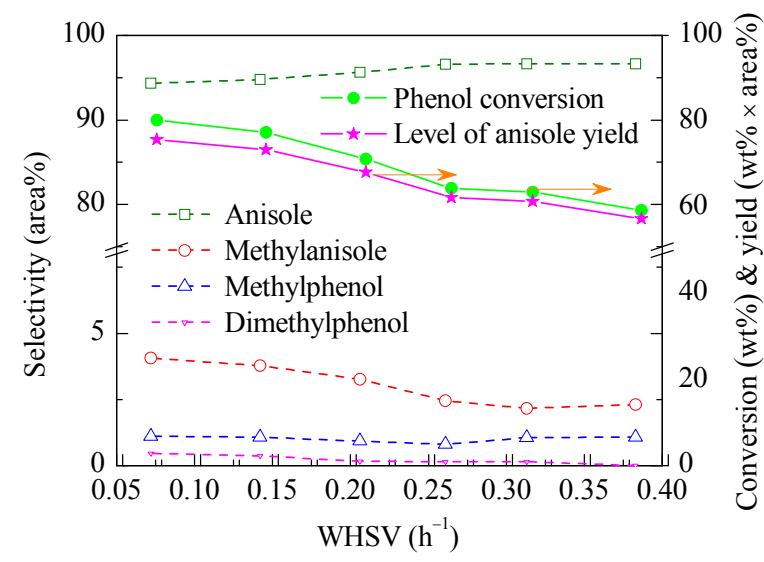

Fig. 7. Effect of WHSV on the performance of $\mathrm{KH}_{2} \mathrm{PO}_{4} / \mathrm{AA}$.

An even lower WHSV will cause an even longer residence time and thus reducing the time efficiency of the process, though it favors the increase of LAY further. So, a preferred WHSV should be determined by optimizing between anisole yield and time efficiency.

\subsubsection{Influence of reactant composition}

Fig. 8 displays the effect of reactant composition on the performance of $\mathrm{KH}_{2} \mathrm{PO}_{4} / \mathrm{AA}$ (K content $7.34 \mathrm{wt} \%$ ). The reaction was conducted under a varied molar ratio of phenol to methanol with a constant temperature of $400{ }^{\circ} \mathrm{C}$ and a WHSV of 0.21 $\mathrm{h}^{-1}$. It can be seen that phenol conversion increased distinctly with increasing mole fraction of methanol. The selectivities of all products, including the main product of anisole, generally varied very little with the increase of mole fraction of methanol. A low methanol fraction favored high anisole selectivity. LAY increased with increasing methanol fraction in a similar trend to that of phenol conversion, and a high LAY over $80 \%$ was obtained when the methanol fraction was 5 times higher than the phenol fraction. The reaction between phenol and methanol to anisole is a process with equal stoichiometric coefficients, and thus an excess of methanol can promote the reaction in the forward direction.

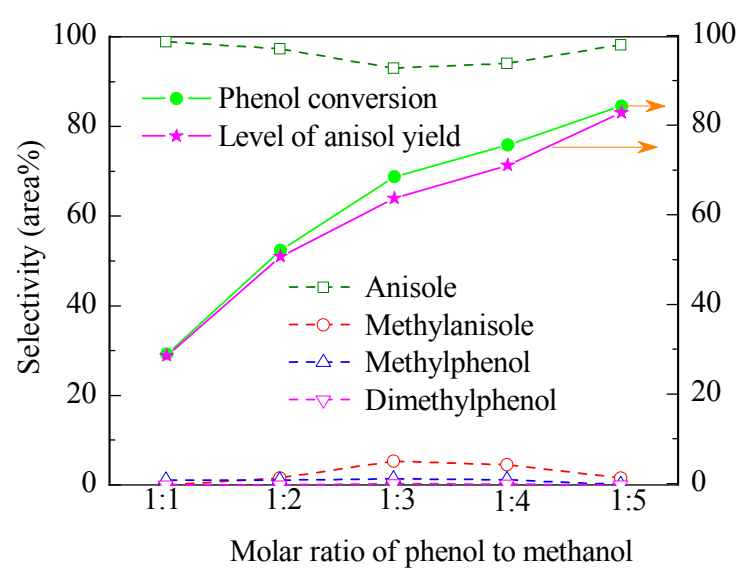

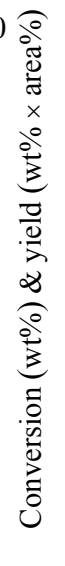

Fig. 8. Effect of mole ratio of phenol to methanol on the performance of $\mathrm{KH}_{2} \mathrm{PO}_{4} / \mathrm{AA}$.

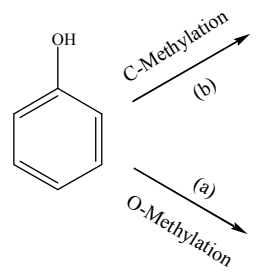<smiles>COc1ccccc1</smiles><smiles>COc1ccccc1C</smiles>

Fig. 9. Reactions routes to the major products.

\subsection{Reactions routes to the major products}

Phenol can be converted to aryl ethers by 0-methylation or to methyl phenols by C-methylation over different catalysts under different conditions. A summary of the above results is that a low reaction temperature, high WHSV meaning a shorter residence time, and low methanol fraction over $\mathrm{KH}_{2} \mathrm{PO}_{4} / \mathrm{AA}$ with a higher $\mathrm{K}$ content favored the increase of anisole selectivity by 0-methylation of phenol. Relatively, the reaction temperature and $\mathrm{K}$ content of the catalyst were the more significant influencing factors.

According to the above results, the reaction routes to the major products can be deduced. As shown in Fig. 9, phenol is first converted to anisole by 0-methylation and to methylphenol by C-methylation in parallel. Route (a) is the dominant one under the optimized reaction conditions as discussed above. The obtained methylphenol and anisole are further converted to dimethylphenol and methylanisole by C-methylation. Methylanisole may also be generated from methylphenol by route (e) beyond route (c), while route (c) would be the preferred one for the formation of methylanisole since the amount of anisole was much higher than that of methylphenol.

\subsection{Catalytic mechanism}

Based on the results given above, the reaction mechanism over $\mathrm{KH}_{2} \mathrm{PO}_{4} / \mathrm{AA}$ was deduced and shown in Fig. 10. In the vapor phase reaction, phenol was adsorbed on the $\mathrm{K}$ sites of the catalyst surface. Methanol was adsorbed on the Lewis acid sites of alumina. The anion of $-\mathrm{OH}$ was removed from methanol by the acidic alumina, generating a separated cation of $\mathrm{CH}_{3}{ }^{+}$. In the presence of $\mathrm{K}$, the $\mathrm{H}^{+}$cation of phenol was replaced by the $\mathrm{K}^{+}$
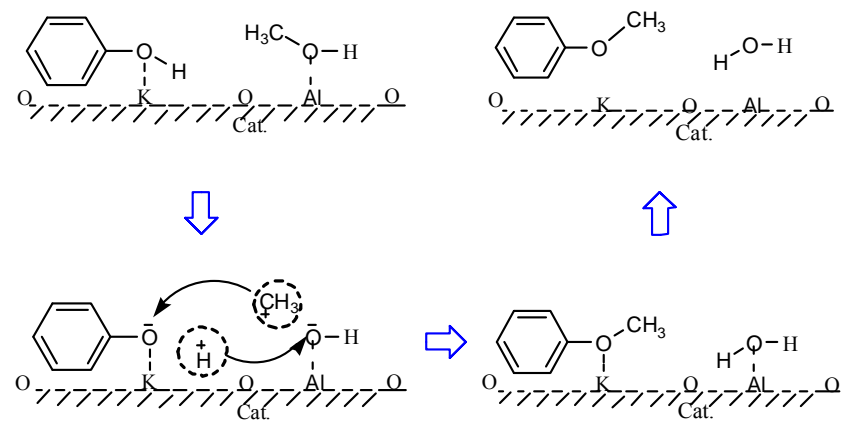

Fig. 10. Catalytic mechanism for the vapor phase methylation of phenol with methanol over $\mathrm{KH}_{2} \mathrm{PO}_{4} / \mathrm{AA}$. 
cation of the catalyst. $\mathrm{CH}_{3}{ }^{+}$from methanol and the $\mathrm{Ph}-\mathrm{O}^{-}$from phenol then combined to give anisole, and water was also generated by the combination of $\mathrm{H}^{+}$and $-\mathrm{OH}$. So, the catalytic mechanism can be attributed to a 'K-acid' bifunctional process. According to this mechanism, an excess of $\mathrm{K}$ can occupy the Lewis acid sites, and thus decrease the activation of methanol, while a low K loading would give decreased activation of phenol. This explains the phenomenon that the catalyst with the best performance has a medium loading.

\section{Conclusions}

Synthesis of anisole by vapor phase methylation of phenol with methanol over activated alumina supported catalysts were investigated in a fixed bed reactor. The $\mathrm{KH}_{2} \mathrm{PO}_{4} / \mathrm{AA}$ catalyst with the calcination temperature of $700{ }^{\circ} \mathrm{C}$ for $8 \mathrm{~h}$ gave the best performance. The optimal $\mathrm{K}$ content was $7.53 \mathrm{wt} \%$. The level of anisole yield has a maximum value at $400-450{ }^{\circ} \mathrm{C}$ in the range from 300 to $500{ }^{\circ} \mathrm{C}$, decreased slightly with increasing WHSV, and increased with increasing mole fraction of methanol. On comparing the O-methylation and C-methylation of phenol, a low reaction temperature, high WHSV, and low methanol fraction over a $\mathrm{KH}_{2} \mathrm{PO}_{4} / \mathrm{AA}$ catalyst with higher $\mathrm{K}$ content favored the increase of anisole selectivity by O-methylation of phenol. The level of anisole yield was maximized under the optimized reaction conditions of around $400-450{ }^{\circ} \mathrm{C}$, low WHSV below $0.18 \mathrm{~h}^{-1}$, and high molar ratio of methanol to phenol of 5 . The catalyst preparation and anisole synthesis process are very simple with low cost and a relatively good result, and thus is advantageous for practical application. The catalytic mechanism was deduced to be that the adsorption of phenol on the $\mathrm{K}$ site of $\mathrm{KH}_{2} \mathrm{PO}_{4} / \mathrm{AA}$ and the adsorption of methanol on the Lewis acid site as the first reaction steps. The following combination of the $\mathrm{CH}_{3}{ }^{+}$of methanol and the $\mathrm{Ph}-\mathrm{O}^{-}$of phenol gave anisole.

\section{References}

[1] G. N. Kirichenko, V. I. Glazunova, A. V. Balaev, U. M. Dzhemilev, Petrol. Chem., 2008, 48, 389-392.

[2] X. J. Song, C. S. Wang, Fine Chem., 2000, 17, 42-44.

[3] Z. H. Fu, Y. Ono, Catal. Lett., 1993, 21, 43-47.

[4] S. Ouk, S. Thiebaud, E. Borredon, P. Le Gars, Green Chem., 2002, 4, 431-435.

[5] G. D. Wu, X. L. Wang, B. Chen, J. P. Li, N. Zhao, W. Wei, Y. H. Sun, Appl. Catal. A, 2007, 329, 106-111.

[6] Y. Ono, Catal. Today, 1997, 35, 15-25.

[7] M. Renavd, P. D. Chantal, S. Kaliaguine, Can. J. Chem. Eng., 1986, 64, 787-791.

[8] S. R. Kirumakki, N. Nagaraju, K. V. R. Chary, S. Narayanan, J. Catal., 2004, 221, 549-559.

[9] S. C. Lee, S. W. Lee, K. S. Kim, T. J. Lee, D. H. Kim, J. C. Kim, Catal. Today, 1998, 44, 253-258.

[10] M. E. Sad, C. L. Padró, C. R. Apesteguía, J. Mol. Catal. A, 2010, 327, 63-72.

[11] K. G. Bhattacharyya, A. K. Talukdar, P. Das, S. Sivasanker, J. Mol. Catal. A, 2003, 197, 255-262.

[12] M. E. Sad, C, L, Padró, C. R. Apesteguía, Appl. Catal. A, 2008, 342, 40-48.

[13] K. Sreekumar, S. Sugunan, J. Mol. Catal. A, 2002, 185, 259-268.

[14] Q. Y. Yu, X. Y. Chou, C. H. Xu, Z. L. Xu, Speciality Petrochem., 2009, $26,12-14$.

[15] L. Xu, S. J. Wu, W. X. Zhang, M. J. Jia, G. Liu, Acta Phys. Chim. Sin., 2009, 25, 242-246.

[16] G. Sarala Devi, D. Giridhar, B. M. Reddy, J. Mol. Catal. A, 2002, 181, 173-178.

\section{Graphical Abstract}

Chin. J. Catal., 2016, 37: 720-726 doi: 10.1016/S1872-2067(15)61074-9

\section{Synthesis of anisole by vapor phase methylation of phenol with methanol over catalysts supported on activated alumina}

Dan Dang, Ze Wang*, Weigang Lin, Wenli Song

Institute of Process Engineering, Chinese Academy of Sciences

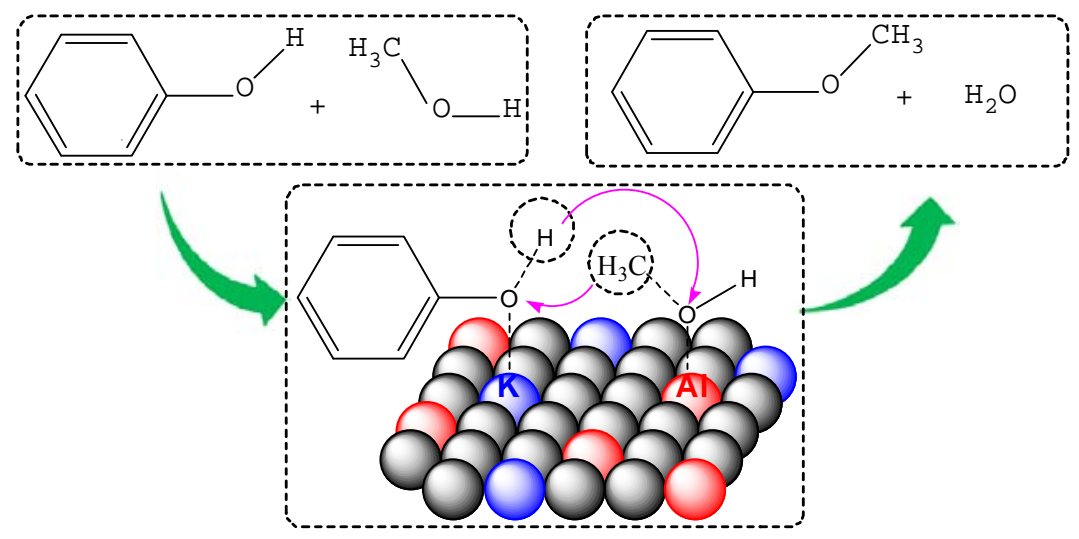

Under catalysis of $\mathrm{KH}_{2} \mathrm{PO}_{4} / \mathrm{Al}_{2} \mathrm{O}_{3}$, phenol and methanol was activated by $\mathrm{K}$ and $\mathrm{Al}$ sites respectively. Anisole yield decreased with increasing space velocity, increased with increasing methanol fraction, and appeared a maximum value with increasing temperature. 


\title{
氧化铝负载催化剂作用下以甲醇为烷基化试剂的苯酚气相转化制备苯甲醚
}

\author{
党丹，王 泽*，林伟刚，宋文立 \\ 中国科学院过程工程研究所, 多相复杂体系国家重点实验室, 北京 100190
}

\begin{abstract}
摘要: 苯甲醚作为重要的化学品和医药中间体而广泛应用于香料、调味剂及有机合成. 液相法是传统的苯甲醚制备工艺, 例如在碱性环境下, 通过酚钠与硫酸二甲酯反应, 溴苯与甲醇反应, 酚钠与氯代甲烷反应均可制得苯甲醚. 然而, 这些方法 具有环境处理负担较重和所用原料毒性较强等不足而备受限制. 因此, 环境友好的绿色苯甲醚合成工艺的开发成为必然, 苯酚的气相烷基化工艺由此提出. 其中, 以碳酸二甲酯 (DMC) 为烷基化试剂的苯酚气相转化苯甲醚制备方法最受关注. $\mathrm{DMC}$ 是常用的绿色高效烷基化试剂, 但其价格相对较高, 在一定程度上增加了苯甲醚制备工艺的复杂性和产品成本. 鉴 于 DMC 可由甲醇经氧化羰基化制得, 因此以甲醇为烷基化试剂的苯酚气相烷基化转化制备苯甲醚方法成为另一研究热 点. 然而, 与 $\mathrm{DMC}$ 的烷基化性能相比, 以甲醇为烷基化试剂的反应产物分布较为复杂, 作为苯酚 $\mathrm{O}$-烷基化 (在苯酚的羟基 氧原子上发生的烷基化) 产物的苯甲醚相对较难获得, 而苯酚的 C-烷基化 (在苯酚的芳环上发生的烷基化) 产物甲基酚产 率更易提高. 总体而言, 与 DMC 烷基化方法相比, 以甲醇为烷基化试剂的苯酚气相转化制备苯甲醚方法有待改善, 相关反 应机理也更欠明晰, 因此具有重要的研究价值.

本文研究了 $\gamma-\mathrm{Al}_{2} \mathrm{O}_{3}(\mathrm{AA})$ 负载型催化剂上以甲醇为烷基化试剂的苯酚气相转化制备苯甲醚方法, 考察了反应温度、气 体空速、苯酚与甲醇配比以及催化剂中 $\mathrm{K}$ 负载量和焙烧温度等对反应性能的影响, 并分析了该体系中的反应机理. 研究表 明, 在 $\mathrm{AA}$ 上负载的 8 种化合物 $\left(\mathrm{NaCl}, \mathrm{MgCl}_{2}, \mathrm{Fe}_{2}\left(\mathrm{SO}_{4}\right)_{3}, \mathrm{Co}\left(\mathrm{NO}_{3}\right)_{2}, \mathrm{ZnCl}_{2}, \mathrm{La}\left(\mathrm{NO}_{3}\right)_{3}, \mathrm{Ce}\left(\mathrm{NO}_{3}\right)_{3}\right.$ 和 $\left.\mathrm{KH}_{2} \mathrm{PO}_{4}\right)$ 的催化剂中, $\mathrm{KH}_{2} \mathrm{PO}_{4} / \mathrm{AA}$ 的催化性能最佳, 相应催化剂中 $\mathrm{K}$ 离子负载量为 $7.53 \mathrm{wt} \%$, 于 $700{ }^{\circ} \mathrm{C}$ 焙烧 $8 \mathrm{~h}$. 苯酚与甲醇气相反应过程中, 苯甲醚最大收率出现在 $400-450{ }^{\circ} \mathrm{C}$, 且随甲醇与苯酚的摩尔比升高而增加, 但随空速的提高而降低. 另外, 在 $\mathrm{KH}_{2} \mathrm{PO}_{4} / \mathrm{AA}^{-}$ 催化剂的高 $\mathrm{K}$ 含量, 以及低温、高空速、低甲醇含量的物料配比的条件下, 对苯酚的 $\mathrm{O}$-烷基化过程有利. 产物除主产物苯

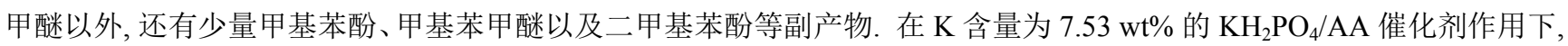
苯甲醚收率最高时反应条件为 $400-450^{\circ} \mathrm{C}$, 空速小于 $0.18 \mathrm{~h}^{-1}$, 甲醇与苯酚摩尔配比为 5 . 本文所开发的催化剂制备方法简 单, 反应条件温和, 产物收率较高, 因此具有较好的应用前景. $\mathrm{X}$ 射线衍射结果显示, 经高温焙烧及固相反应后, $\mathrm{KH}_{2} \mathrm{PO}_{4} / \mathrm{AA}$ 催化剂中产生了 $\mathrm{K}_{3} \mathrm{Al}_{2}\left(\mathrm{PO}_{4}\right)_{3}$ 新物相. 推测该反应机理是酸性氧化铝促进甲醇脱羟基负离子以及 $\mathrm{K}$ 离子促进酚羟基脱氢质 子,所形成的甲基正离子进一步与苯氧基负离子结合得到苯甲醚的“钾离子-酸”双功能催化作用过程.
\end{abstract}

关键词: 苯酚; 甲醇; 催化; 苯甲醚; 甲基化

收稿日期: 2016-02-19. 接受日期: 2016-02-25. 出版日期: 2016-05-05.

*通讯联系人. 电话: (010)82544963; 传真: (010)82622893; 电子信箱: wangze@ipe.ac.cn

基金来源：国家自然科学基金(51476180); 国家重点基础研究发展计划(973 计划, 2014CB744304).

本文的英文电子版由Elsevier出版社在ScienceDirect上出版(http://www.sciencedirect.com/science/journal/18722067). 